\title{
ANALISIS ZAT GIZI MAKRO DARI TEPUNG KOMBINASI KAKAO (Theobroma cacao L) DAN UBI KAYU (Manibot utilissima) SEBAGAI BAHAN DASAR BISKUIT
}

\section{Analysis of Macro Nutrient in the Combined Flour of Cocoa (Theobroma cacao L) and Cassava (Manihot utilissima) as A Raw Ingredients for Biscuits}

\author{
*Hairunnisa, Suherman, dan Supriadi \\ Pendidikan Kimia/FKIP - Universitas Tadulako, Palu - Indonesia 94118 \\ Received 04 September 2017, Revised 05 October 2017, Accepted 03 November 2017
}

\begin{abstract}
This study aims to determine the moisture content, ash, carbohydrate, protein and fat from a combination of flour cocoa and cassava as raw material manufacture of biscuits, as well as knowing the favorite test (favorite level) of the biscuits that have been made with several variations of flour cocoa and cassava. The method used is the gravimetric method, combustion method, phenol method, kjedhal method, and soxhlet method.The results showed that the combination of cocoa powder and cassava with some variation of that,variation A (25\%:75\%) had a moisture level of $18.0 \%, 2.2 \%$ ash, $2.7 \mathrm{mg} / 100 \mathrm{~g}$ carbohydrates, $1.7 \%$ protein, and $7.2 \%$ fat. Variation B (50\%: 50\%) had a moisture level of 4.0\%, 3.4\% ash, $63.9 \mathrm{mg} / 100$ gcarbohydrates, $4.8 \%$ protein, and $19.2 \%$ fat. Variation C (75\%:25\%) had a moisture level of 2.0\%, $9.4 \%$ ash, $127.9 \mathrm{mg} / 100$ gcarbohydrates, $6.7 \%$ protein, and $27.4 \%$ fat. These results indicated that the levels of nutrients in the combination of cocoa and cassava flours increased with increasing variations, especially for ash, carbohydrates, protein, and fat levels with the addition of cocoa flour by $75 \%$ but the moisture level decreased, and the biscuit trials shown that the best treatment was the Variation B (50\%: 50\%).
\end{abstract}

Keywords: Cocoa flour, cassava flour, biscuits, makro nutrient.

\section{Pendahuluan}

Tepung terigu di Indonesia sangat dibutuhkan dalam industri pangan, tepung tersebut semakin meningkat dengan makin banyaknya industri pangan yang produknya berbahan dasar tepung terigu. Tingkat konsumsi Indonesia terhadap produk tepung terigu sangat tinggi, berdasarkan data yang dihimpun APTINDO (Asosiasi Pengusaha Tepung Terigu Indonesia) konsumsi tepung terigu tahun 2013 mencapai 5,35 juta ton, lebih tinggi dari 2012 sebanyak 4,6 juta ton. Kapasitas produksi gandum nasional masih rendah yaitu $<10 \%$ dari total kebutuhan gandum untuk produksi tepung terigu dalam negeri. Kekurangan ini karena tanaman gandum sebagai bahan dasar tepung terigu merupakan tanaman sub-tropis, sehingga tanaman ini kurang optimal pertumbuhannya di Indonesia yang beriklim tropis dan mengakibatkan kekurangan pasokan terigu yang kemudian diatasi dengan impor dari negera lain (APTINDO, 2014).

Berbagai upaya dilakukan untuk memenuhi bahan baku pembuatan tepung yang berasal dari bahan baku lokal, dimana hal ini menjadi suatu tantangan dan peluang untuk pengembangan produk lokal. Oleh karena itu diperlukan sumber karbohidrat dari bahan pangan yang lain dalam pengolahan pangan. Hal yang penting dilakukan

*Correspondence

Hairunnisa

Program Studi Pendidikan Kimia, Fakultas Keguruan dan IImu Pendidikan, Universitas Tadulako

e-mail: chairunnisa2284@gmail.com

Published by Universitas Tadulako 2017 adalah mensubstitusikan tepung terigu dari sumber bahan pangan lain untuk dijadikan tepung dalam pembuatan produk makanan, seperti subtitusi tepung terigu dari tepung biji kakao dan tepung ubi kayu (Suherman, dkk., 2014).

Kakao (Theobroma cacao L) adalah pohon budidaya perkebunan yang berasal dari Amerika Selatan, namun sekarang ditanam di berbagai kawasan tropika seperti Indonesia. Menurut Sovia(1978)kakao merupakan tumbuhan tahunan (perennial) berbentuk pohon, di alam dapat mencapai ketinggian $10 \mathrm{~m}$. Tetapi, dalam pembudidayaan tingginya dibuat tidak lebih dari $5 \mathrm{~m}$ dengan tajuk menyamping yang meluas.

Ubi kayu termasuk tanamanpangan yang sudah lama dibudidayakan secaratradisional di Indonesia dan sudah dikenal luas di masyarakat. Ubi kayu memiliki beberapa kegunaan, antara lainsebagai bahan pangan, juga dapat digunakansebagai bahan baku industri dan pakan ternak(Herlina \& Nuraeni, 2014).Ubi kayu (Manihot utilissima) termasuk tumbuhan berbatang pohon lunak atau getas (mudah patah). Ubi kayu berbatang bulat dan bergerigi yang terjadi dari bekas pangkal tangkai daun, bagian tengahnya bergabus dan termasuk tumbuhan yang tinggi (Tjitrosoepomo, 1998).

Kakao dan ubi kayu dapat memberikan berbagai manfaat dalam berbagai bidang seperti industri makanan dan farmasi. Hal ini dikarenakan buah kakao dan ubi kayu memiliki kandungan zat gizi yang sangat bermanfaat yaitu diataranya kadar air, abu, protein, lemak, karbohidrat, serat dan lain sebagainya, sehingga sangat baik jika dijadikan tepung untuk pengganti 
tepung terigu dalam pembuatan biskuit (Suherman, dkk., 2014).

Biskuit merupakan salah satu makanan ringan atau snack yang banyak dikonsumsi oleh masyarakat. Produk ini merupakan produk kering yang memiliki kadar air rendah. Berdasarkan Badan Standarisasi Nasional(1992)biskuit adalah produk yang diperoleh dengan memanggang adonan dari tepung terigu dengan penambahan zat makanan lain atau tanpa zat-zat logam.

Tulisan ini dimaksudkan untuk mendeskripsikan kadar zat gizi makro yang meliputi air, abu, karbohidrat, protein, dan lemak dari kombinasi tepung kakao (Theobroma cacao L) dan ubi kayu (Mannihot Utilissima)serta untuk mengetahuiuji kesukaan (tingkat kesukaan) terhadap biskuit yang telah dibuat dengan beberapa variasi tepung kakao dan ubi kayu.

\section{Metode}

\section{Alat dan Bahan}

Alat yang digunakan dalam penelitian ini yaitu pipet tetes, neraca digital ARC-120, wadah, stopwatch, oven MMM medcenter, blender, alat ekstraksi soxhlet Gerhadrt SE-412, kertas saring, kapas, cawan porselen, desikator, pemanas listrik, tanur FB1410M, labu Kjeldahl, evaporator SB 1100, Erlenmeyer, gelas kimia, labu ukur, pipetukur, gelas ukur, gegep (penjepit), karet penghisap, shaker model VRN-480, kaca arloji, tabung reaksi, rak tabung reaksi, kuvet, tabung vial, spatula, batang pengaduk, tissue, botol semprot, corong, gunting, aluminium foil, spektrofotometer UV/Vis T80+PG Instrumen Ltd, spektrodirect RS232 serial No: 1257060900344 , mixer, wadah.

Bahan yang digunakan dalam penelitian ini adalah biji kakao, ubi kayu, n-hexana, aquades, $\mathrm{H}_{2} \mathrm{SO}_{4}$ (Merck), arang aktif, larutan fenol 5\% $($ KgaA $)$, glukosa (Merck), tablet kjeldhal $\left(\mathrm{K}_{2} \mathrm{SO}_{4}\right.$ (Merck) dan $\mathrm{HgO}($ Merck)), mentega (Blue Band), susu bubuk (Dancow), gula halus (Cap Tebu Lapan), kuning telur ayam, spikel (Cap Cendrawasih).

\section{Prosedur Penelitian}

Perlakuan yang digunakan dalam penelitian ini adalah penggunaan tepung kakao dan tepung ubi kayu yang divariasikan ke dalam produk biskuit yaitu perbandingan 25:75, 50:50, 75:25.

\section{Penyiapan sampel}

Pemilihan biji kakao dan ubi kayu yang diambil yaitu dalam keadaan baik, tidak terserang hama maupun penyakit. Biji kakao dan ubi kayu yang sudah disortir kemudian dicuci berulang kali sampai bersih, setiap kali dicuci airnya diganti. Setelah itu, untuk biji kakao selanjutnya dikeringkan dengan bantuan cahaya matahari (Hutepea, 2010) dan untuk ubi kayu setelah dicuci selanjutnya diiris tipis-tipis dengan ketebalan 0,3$0,4 \mathrm{~cm}$ (Kurniawan, 2010).

\section{Proses Pembuatan Tepung}

\section{Tepung kakao}

Sampel biji kakao yang telah disiapkan pada tahap sebelumnya dikeringkan di dalam oven dengan suhu $80^{\circ} \mathrm{C}$ selama 1 hari.Setelah itu, biji kakao didiamkan pada suhu kamar. Selanjutnya biji kakao dihaluskan dan diayak dengan ayakan ukuran 80 mesh(Reski, 2012).

\section{Tepung ubi kayu}

Sampel ubi kayu yang telah disiapkan pada tahap sebelumnya direndam selama 2 hari menggunakan air kapur yang dilarutkan dengan air bersih. Perendaman ubi skayu dilakukan sedemikian rupa sehingga seluruh ubi kayu tertutup air. Setelah itu, ubi kayu dicuci kembali hingga bersih. Kemudian, ubi kayu dikeringkan di udara luar/oven dengan suhu $50{ }^{\circ} \mathrm{C}$. Selanjutya ubi kayu dihaluskan dan diayak dengan ayakan ukuran 80 mesh (Kurniawan, 2010).

\section{Prosedur pembuatan biskuit}

50 gram mentega, 1 sachet susu bubuk, dan 25 gramgula halus dimasukkan ke dalam wadah, kemudian dicampur dan diaduk dengan menggunakan mixer selama lima menit. Setelah itu, 2 butir kuning telur dimasukkan ke dalam wadah sebelumnya dan diaduk dengan mixer selama sepuluh menit. Selanjutnya tepung kakao dan tepung ubi kayu yang telah dikombinasikan dimasukkan dan dicampur sampai homogen pada wadah sebelumnya. Adonan yang sudah homogen dicetak dan diletakkan diatas loyang yang telah diolesi mentega.Loyang berisi adonan dipanggang dengan oven pada suhu $180^{\circ} \mathrm{C}$ selama 15 menit.

\section{Proses Pengujian Tepung}

\section{Kadar air}

Pengujian kadar air dilakukan dengan metode gravimetri. Kaca arloji dikeringkan dalam oven selama 30 menit, lalu didinginkan di dalam desikator dan ditimbang. Sampel 5 gram ditimbang lalu dimasukkan kedalam kaca arloji dan dikeringkan di dalam oven pada suhu $105^{\circ} \mathrm{C}$ selama 4 jam. Selanjutnya didiamkan pada suhu kamar. Setelah itu didinginkan dalam desikator selama 20 menit dan kemudian ditimbang.

Kadar air dapat dihitung dengan rumus (Sudarmadji, 1989):

$$
\text { Kadar air }(\%)=\frac{\text { (berat kaca arloji kosong }+ \text { sampel })-(\text { berat kaca arloji }+ \text { sampel setelah dipanaskan) }}{\text { berat sampel }} \times 100 \%
$$

\section{Kadar abu}

Pengujian kadar abu dilakukan dengan metode pembakaran. Cawan porselen yang bersih terbebas dari kotoran dipanaskan dalam oven selama 1 jam pada suhu $105^{\circ} \mathrm{C}$ lalu didinginkan dalam desikator selama 15 menit kemudian di timbang. Sampel ditimbang sebanyak 10 gram dan dimasukan dalam cawan. Cawan yang berisi sampel diabukan di dalam tanur hingga tidak berasap. Pengabuan dengan tanur pada suhu 600 
${ }^{\circ} \mathrm{C}$ selama 3 jam. Setelah pengabuan cawan didinginkan pada suhu kamar. Selanjutnya didinginkan di dalam desikator, setelah didinginkan cawan ditimbang. Kadar abu dapat dihitung dengan rumus(Sudarmadji, 1989):

$$
\text { Kadar abu }(\%)=\frac{(\text { berat cawan }+ \text { abu })-\text { berat cawan } \text { kosong }}{\text { berat sampel }} \times 100 \%
$$

\section{Kadar karbohidrat}

Penentuan kadar karbohidrat dilakukan dengan metode Fenol. Sampel 1 gram ditimbang gram, kemudian dimasukkan ke dalam erlenmeyer dan ditambahkan $50 \mathrm{~mL}$ aquades, lalu ditutup menggunakan aluminium foil. Selanjutnya dishaker selama 1 jam, setelah itu ditambahkan arang aktif dan dikocok. Selanjutnya, sampel disaring dengan menggunakan kertas saring. Kemudian, dipindahkan ke dalam Erlenmeyer dan ditambahkan $0,5 \mathrm{~mL}$ larutan fenol $5 \%$ dan $2,5 \mathrm{~mL}$ $\mathrm{H}_{2} \mathrm{SO}_{4}$ dalam larutan sampel. Dilanjutkan pendiaman selama 10 menit kemudian divorteks dan didiamkan lagi selama 20 menit. Kadar karbohidrat diukur menggunakan spektrofotometer UV/Vis pada panjang gelombang $490 \mathrm{~nm}$. Untuk pembuatan larutan standar 10 ppm, $20 \mathrm{ppm}, 30 \mathrm{ppm}, 40 \mathrm{ppm}$ dan $50 \mathrm{ppm}$, padatan glukosa ditimbang sebanyak 0,1 gram dimasukkan ke dalam labu ukur $100 \mathrm{~mL}$ dan ditambahkan aquades hingga tanda batas dan diencerkan. Untuk 10 ppm diambil sebanyak 0,5 $\mathrm{mL}$, Untuk $20 \mathrm{ppm}$ diambil sebanyak $1 \mathrm{~mL}$, Untuk $30 \mathrm{ppm}$ diambil sebanyak 1,5 mL, Untuk $40 \mathrm{ppm}$ diambil sebanyak $2 \mathrm{~mL}$ dan untuk 50 ppm diambil sebanyak 2,5 mL dan dimasukkan ke dalam labu ukur $50 \mathrm{~mL}$. Kemudian ditambahkan aqudes hingga tanda batas dan diencerkan. Kadar karbohidrat dapat dihitung dengan rumus (Sudarmadji, 1989):

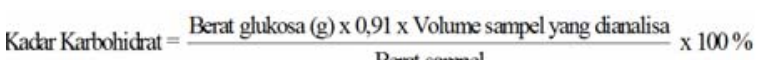

\section{Kadar protein}

Penentuan kadar protein dilakukan dengan cara metode Kjeldahl. Ditimbang 5 gram sampel dan dimasukkan dalam labu kjeldahl, ditambahkan 1 butir tablet kjeldahl dan $10 \mathrm{~mL} \mathrm{H}_{2} \mathrm{SO}_{4}$ pekat, kemudian didestruksi (dipanaskan) semua bahan dalam labu Kjeldahl sampai mendidih hingga larut dalam labu Kjeldahl dan cairan menjadi jernih. Selanjutnya diencerkan dengan $75 \mathrm{~mL}$ aquades, lalu didinginkan sampai suhu kamar. Selanjutnya, diambil sebanyak $10 \mathrm{~mL}$ larutan hasil destruksi. Kemudian diukur kadar nitrogen total pada panjang gelombang $410 \mathrm{~nm}$ menggunakan spektrodirect.

Kadar protein dapat dihitung dengan rumus (Sudarmadji, 1989): $\%$ protein $=\frac{\mathrm{N} \times \text { Faktor pengenceran } \times 6,25 \times \text { jumlah } \mathrm{mL} \text { sampel }}{\text { Berat sampel }} \times 100 \%$

\section{Kadar lemak}

Pengujian kadar lemak dilakukan dengan metode soxhlet. Labu alas bulat kosong dioven selama 1 jam dan kemudian ditimbang. Setelah itu 5 gram sampel ditimbang, dibungkus dengan kertas saring dan dimasukkan dalam tabung ekstraksi soxhlet, kemudian dipasang alat kondensor diatasnya dan labu di bawah alat soxhlet. Selanjutnya, pelarut heksana diisi ke dalam labu dan dilakukan proses refluks sampai pelarut turun kembali ke labu dan hasilnya berwarna jernih. Labu dipanaskan sampai pelarutnya mendidih dan menguap naik ke sampel yang dibungkus kertas saring dan turun ke labu dan seterusnya. Proses evaporasi pelarut yang telah mengandung ekstrak lemak dalam labu, dan menampung pelarutnya. Hasil ekstrak lemak yang terdapat pada labu alas bulat kemudian dimasukkan ke dalam oven pada suhu $105^{\circ} \mathrm{C}$, lalu didinginkan dalam desikator kemudian ditimbang sampai beratnya tetap. Perlakuan diulang untuk sampel berikutnya (Apriantono, dkk., 1989).

$\operatorname{Kadar} \operatorname{Lemak}(\%)=\frac{\text { (berat labu alas bulat }+ \text { lemak })- \text { labu alas bulat kosong }}{\text { berat sampel }} \times 100 \%$

\section{Uji kesukaan}

Uji kesukaan dilakukan oleh 20 panelis yang terdiri dari konsumen dan produsen. Dimana panelis diminta untuk memberikan penilaian berdasarkan tingkat kesukaannya yaitu: 1 . Sangat Suka; 2. Suka; 3. Tidak Suka.

\section{Hasil dan Pembahasan}

Dalam penelitian ini dilakukan analisis kadar zat gizi makro yang meliputi air, abu, karbohidrat, protein, dan lemak daritepung kombinasi kakao (Theobroma cacao L) dan ubi kayu (Manihot utilissima)dengan variasi kombinasi seperti terlihat pada Tabel 1.

Tabel 1.Variasi tepung kombinasi kakao dan ubi kayu

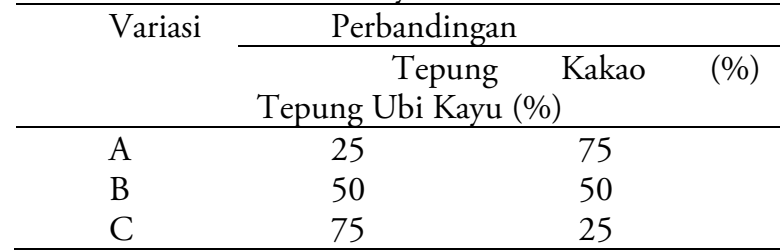

Adapun hasil penelitian yang diperoleh dari tiap-tiap pengujian yaitu dapat dilihat pada Tabel 2 dan 3.

Tabel 2.Data hasil pengamatan tepung kombinasi kakao dan ubi kayu dari tiap-tiap pengujian.

\begin{tabular}{cccc}
\hline \multirow{2}{*}{ Parameter } & \multicolumn{3}{c}{ Variasi } \\
\cline { 2 - 4 } & A & B & C \\
\hline Kadar air (\%) & 18,0 & 4,0 & 2,0 \\
Kadar abu (\%) & 2,2 & 3,4 & 9,4 \\
KadarKarbohidrat(mg/100g) & 2,7 & 63,9 & 127,9 \\
Kadar Protein (\%) & 1,7 & 4,8 & 6,7 \\
Kadar Lemak (\%) & 7,2 & 19,2 & 27,4 \\
\hline
\end{tabular}


Tabel 3. Data hasil pengamatan tingkat kesukaan panelis terhadap biskuit yang terbuat dari beberapa variasi tepung kombinasi

\begin{tabular}{cccc}
\hline \multirow{2}{*}{$\begin{array}{c}\text { VariasiTepungKom } \\
\text { binasi }\end{array}$} & \multicolumn{3}{c}{ Tingkat Kesukaan } \\
\cline { 2 - 4 } & $\begin{array}{c}\text { Sangat } \\
\text { Suka }\end{array}$ & Suka & $\begin{array}{c}\text { TidakS } \\
\text { uka }\end{array}$ \\
\hline A & $40 \%$ & $55 \%$ & $5 \%$ \\
B & $65 \%$ & $35 \%$ & $0 \%$ \\
C & $30 \%$ & $55 \%$ & $15 \%$ \\
\hline
\end{tabular}

\section{Kadar air}

Peranan air dalam bahan pangan dinyatakan sebagai aktivitas air. Dalam bahan pangan, air terutama berperan sebagai pelarut yang digunakan selama proses metabolisme (Pongsawatmanit, dkk., 2002).

Analisis air dilakukan untuk mengetahui tingkat kadar air pada variasi tepung kombinasi kakao dan ubi kayu. Kadar air merupakan banyaknya air yang terkandung dalam bahan yang dinyatakan dalam persen.Menurut Winarno (2004)kadar air dalam bahan pangan ikut menentukan kesegaran dan daya awet bahan pangan tersebut, kadar air yang tinggi mengakibatkan mudahnya bakteri, kapang, dan khamir untuk berkembang biak, sehingga akan terjadi perubahan pada bahan pangan. Makin rendah kadar air, makin lambat pertumbuhan mikroorganisme berkembang biak, sehingga proses pembusukan akan berlangsung lebih lambat. Selain itu kadar air dalam bahan pangan juga ikut berperan dalam pembentukan sifat organoleptik dari suatu produk.

Penentuan kadar air dari tepung kombinasi kakao dan ubi kayu menggunakan metode gravimetri. Metode gravimetri yaitu analisis kimia secara kuantitatif berdasarkan proses pemisahan dan penimbangan suatu unsur atau senyawa tertentu dalam bentuk yang murni. Prinsipnya, kehilangan bobot pada pemanasan $105^{\circ} \mathrm{C}$ dianggap sebagai kadar air yang terdapat pada sampel.

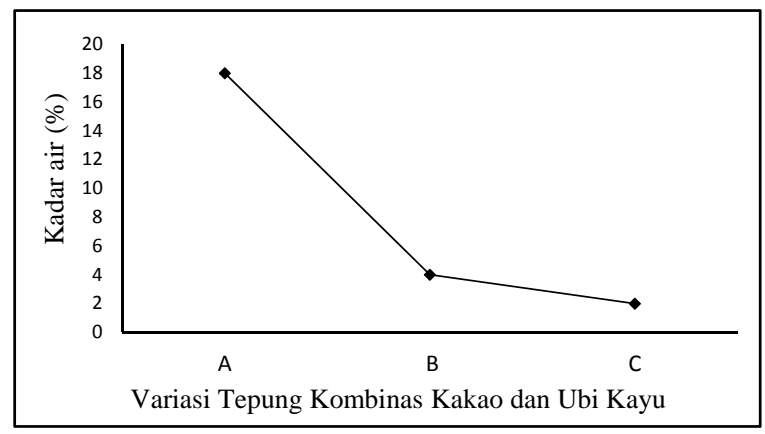

Gambar 1.Hubungan Antara Kadar Air dengan Variasi Tepung Kombinasi Kakao dan Ubi Kayu.

Berdasarkan Gambar 1, hasil analisa kadar air tepung kombinasi kakao dan ubi kayu yang dihasilkan, menunjukkan bahwa kadar air pada variasi A memiliki nilai kadar air yang lebih tinggi yaitu $18 \%$ sedangkan pada variasi $\mathrm{C}$ memiliki nilai kadar air terendah yaitu 2\%. Hal ini disebabkan karena adanya perbedaan variasi tepung kombinasi kakao dan ubi kayu yang diberikan, dimana semakin banyak penambahan tepung ubi kayu maka semakin tinggi kadar air pada tepung kombinasi tersebut. Hal ini sesuai denganpendapatKurniawan(2010)yang

menyatakan bahwa kadar air dari tepung mocaf (tepung ubi kayu) meningkat seiring dengan lamanya perendaman dilakukan. Jika dibandingkan dengan tepung kakao, kadar air pada tepung ubi kayu (mocaf) lebih tinggi yaitu 13\% dibandingan dengan kadar air pada tepung kakao yaitu $5 \%$.

\section{Kadar $a b u$}

Abu merupakan zat anorganik sisa hasil pembakaran suatu bahan organik.Penentuan kadar abu total dapat digunakan untuk berbagai tujuan, antara lain untuk menentukan baik atau tidaknya suatu pengolahan, mengetahui jenis bahan yang digunakan dan sebagai penentu parameter nilai gizi suatu bahan makanan(Sudarmadji, 1989).

Penentuan kadar abu dari tepung kombinasi kakao dan ubi kayu menggunakan metode pembakaran. Metode pembakaran disebut juga dengan pengabuan kering, dimana pengabuan kering dilakukan dengan cara mendestruksi komponen organik sampel dengan suhu tinggi (sekitar $500-600 \quad{ }^{\circ} \mathrm{C}$ ) di dalam suatu tanur pengabuan (furnace), tanpa terjadi nyala apisampai terbentuk abu berwarna putih keabuan dan berat konstan tercapai.

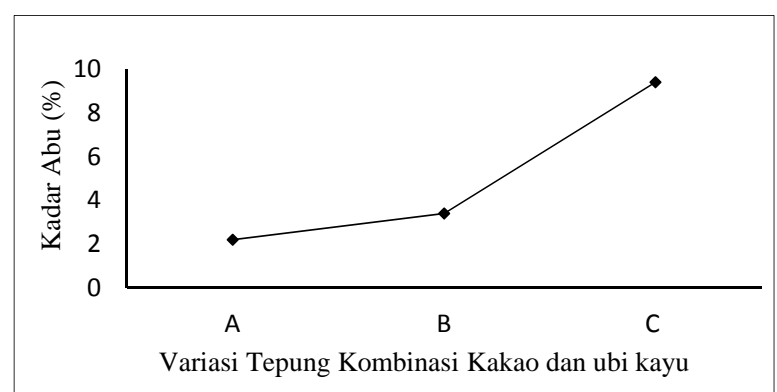

Gambar 2.Hubungan Antara Kadar Abu dengan Variasi Tepung Kombinasi Kakao dan Ubi Kayu.

Berdasarkan Gambar 2, hasil analisa kadar abu tepung kombinasi kakao dan ubi kayu yang dihasilkan, menunjukkan bahwa kadar abu pada variasi A memiliki nilai kadar abu yaitu $2,2 \%$, variasi $B$ yaitu 3,4\%, dan variasi $C$ yaitu $9,4 \%$. Hal ini menunjukkan semakin banyak tepung kakao yang ditambahkan maka persen kadar abu yang dihasilkan semakin tinggi. Jika dibandingkan dengan kadar abu awal dari tepung kakao dan ubi kayu, kadar abu meningkat pada variasi C. Hal ini sesuai dengan pendapat Anonim (2010) bahwa kadar abu yang tinggi pada bahan tepung kurang disukai karena cenderung memberi warna gelap pada produknya. Semakin rendah kadar abu pada produk tepung akan semakin baik, karena kadar 
abu selain mempengaruhi warna akhir produk juga akan mempengaruhi tingkat kestabilan adonan.

\section{Kadar karbohidrat}

Karbohidrat dalam tepung terdiri dari karbohidrat dalam bentuk gula sederhana, pentosa, dextrin, selulosa, dan pati (Setiyono, 2011). Sebagian besar karbohidrat, terutama golongan monosakarida dan disakarida seperti glukosa, fruktosa, galaktosa, dan laktosa mempunyai sifat mereduksi. Sifat mereduksi dari karbohidrat disebabkan oleh adanya gugus aldehida atau gugus keton bebas dan gugus -OH bebas (Daud, dkk., 2012).

Penentuan kadar karbohidrat diukur dengan menggunakan metode fenol. Prinsip dari metode ini adalah gula sederhana, oligosakarida, polisakarida dapat bereaksi dengan fenol dalam asam sulfat pekat menghasilkan warna jingga kekuningan yang stabil. Polisakarida dan oligoskarida dihidrolisis menjadi monosakarida oleh asam sulfat pekat dan menghidrasinya sehingga membentuk senyawa furfural yang bereaksi dengan fenol menghasilkan warna jingga kekuningan (Bintang, 2010).

Sampel diperlakukan sama seperti pada larutan standar yang menghasilkan warna jingga kekuningan, kemudian dilakukan pengukuran absorban larutan glukosa standar pada konsentrasi $10,20,30,40$, dan $50 \mathrm{ppm}$ pada panjang gelombang $490 \mathrm{~nm}$. Hal ini bertujuan untuk memperoleh konsentrasi sampel dengan menggunakan persamaan regresi yang diperoleh dari pengukuran absorbansi larutan standar, yaitu adalah $y=0,017 x+0,060$. Berdasarkan persamaan regresi, maka diperoleh konsentrasi sampel tepung kombinasi kakao dan ubi kayu secara berturutturut adalah $0,58 \mathrm{ppm}, 14,05 \mathrm{ppm}$, dan 28,11 ppm, kemudian dengan menggunakan rumus yang telah ditetapkan sebelumnya, kadar karbohidrat dari masing-masing sampel diperoleh dan dapat dilihat pada Gambar 3.

Berdasarkan Gambar 3, terlihat bahwa kadar karbohidrat pada variasi tepung $\mathrm{C}$ lebih tinggi dibandingkan pada variasi A dan B. Kadar karbohidrat dari masing-masing variasi yaitu berturut-turut $2,7 \mathrm{mg} / 100 \mathrm{gram}, 63,9 \mathrm{mg} / 100 \mathrm{gram}$, dan $127,9 \mathrm{mg} / 100 \mathrm{gram}$. Hal ini disebabkan karena adanya perbedaan variasi tepung kombinasi

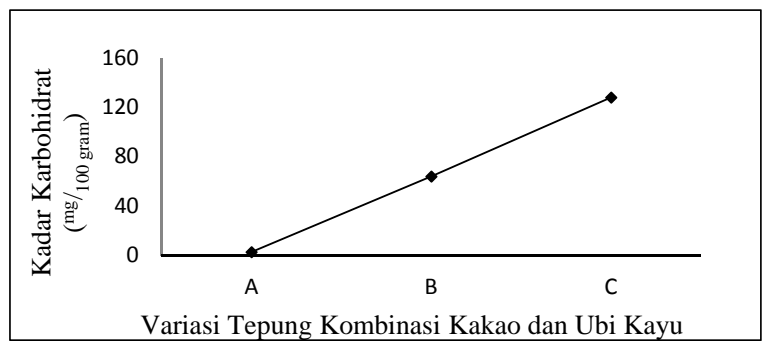

Gambar 3. Hubungan antara kadar karbohidrat dengan variasi tepung kombinasi kakao dan ubi kayu. kakao dan ubi kayu yang diberikan, dimana semakin banyak penambahan tepung ubi kayu maka semakin rendah kadar karbohidrat pada tepung kombinasi tersebut. Menurut Winarno (2004) pati merupakan karbohidrat yang terbesar dalam tanaman berklorofil. Salah satunya umbi singkong yang mengandung pati $80 \%$. Menurut Sadli (2014) faktor penyebab penurunan kadar karbohidrat (pati) dalam suatu sampel adalah pada saat proses penyaringan, dimana berkurangnya kadar pati dapat terjadi karena adanya partikelpartikel pati yang lebih besar yang tidak melewati saringan, sehingga jumlah pati pada saat pengukuran menjadi lebih sedikit.

Menurut Sediaoetama (2008) di dalam hidangan karbohidrat memudahkan pemberian bentuk kepada makanan, misalnya dalam bentuk kue. Jika dipanaskan pada suhu tinggi, karbohidrat menjadi karamel yang memberikan aroma khusus. Kerjasama antara karbohidrat dan protein tertentu di dalam tepung terigu memberikan hasil makanan yaitu misalnya roti menjadi empuk seperti spons. Dalam pangan, karbohidrat khususnya mono- dan disakarida, memberi rasa manis pada makanan (Tejasari, 2005).

\section{Kadar protein}

Protein merupakan sumber asam amino yang mengandung unsur-unsur $\mathrm{C}, \mathrm{H}, \mathrm{O}$ dan $\mathrm{N}$ yang tidak dimiliki oleh lemak dan karbohidrat.Protein merupakan komponen yang banyak terdapat pada sel tanaman dan hewan.Kandungan protein dalam bahan pangan bervariasi baik dalam jumlah maupun jenisnya.Protein merupakan sumber gizi utama, yaitu sebagai sumber asam amino. Protein dari sumber yang berbeda memiliki kekhasan sifat fungsional yang berpengaruh pada karakteristik produk pangan (Qalsum, 2015). Adanya kandungan unsur $\mathrm{N}$ maka dalam penentuan jumlah protein dapat dilakukan dengan cara menentukan jumlah nitrogen $(\mathrm{N})$ yang ada dalam bahan pangan. Penentuan jumlah $\mathrm{N}$ total dilakukan untuk mewakili jumlah protein yang ada dan metode pengukuran kadar protein ini adalah metode Kjeldahl dimana pengukuran didasarkan atas pengukuran kandungan nitrogen total didalam bahan pangan. Bila dikalikan hasil analisis tersebut dengan faktor konversi 6,25, maka diperoleh nilai protein dalam bahan makanan tersebut (Novika, dkk., 2013). Unsur nitrogen adalah unsur utama protein, karna terdapat didalam semua protein yang memiliki proporsi $16 \%$ dari total protein.Kadar protein untuk masing-masing sampel dapat dilihat pada Gambar 4.

Gambar 4 memperlihatkan bahwa kadar protein pada tepung kombinasi kakao dan ubi kayu pada variasi A lebih rendah jika dibandingkan dengan variasi $\mathrm{B}$ dan $\mathrm{C}$. Kadar protein dari masing-masing sampel yaitu berturut-turut $1,7 \%$, $4,8 \%, 6,7 \%$.

Gluten adalah suatu senyawa pada tepung yang bersifat kenyal dan elastis, yang diperlukan 
dalam pembuatan kue atau roti agar dapat mengembang dengan baik dan menentukan daya

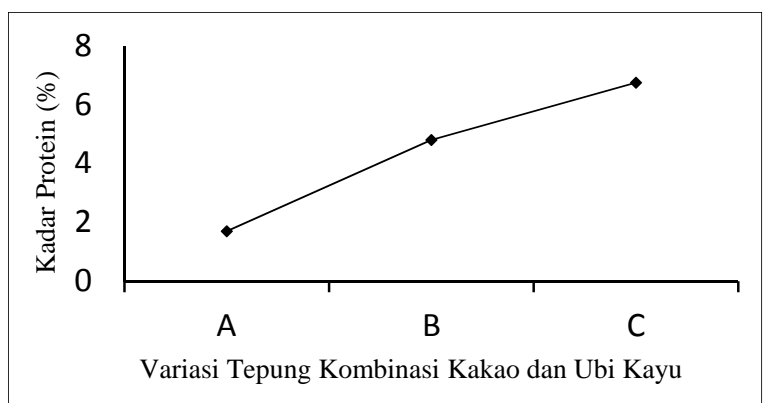

Gambar 4. Hubungan antara kadar protein dengan variasi tepung kombinasi kakao dan ubi kayu.

patah dari kue, dapat menentukan kekenyalan mie serta berperan dalam pembuatan kulit martabak telur supaya tidak mudah robek. Umumnya kandungan gluten menentukan kadar protein tepung terigu, semakin tinggi kadar gluten, semakin tinggi kadar protein tepung terigu tersebut. Kadar gluten pada suatu tepung menentukan kualitas pembuatan suatu makanan.Dalam pembuatan makanan, hal yang harus diperhatikan ialah ketepatan penggunaan jenis tepung. Tepung terigu berprotein 12\%-14\% ideal untuk pembuatan roti dan mie, $10,5 \%$ $11,5 \%$ untuk biscuit, pastry/pie dan donat sedangkan untuk gorengan, cake dan wafer gunakan yang berprotein 8\%-9\% (Igfhar, 2012).

\section{Kadar lemak}

Lemak dan minyak adalah salah satu kelompok yang termasuk pada golongan lipid, yaitu senyawa organik yang terdapat dialam serta tidak larut dalam air, tetapi larut dalam pelarut organik non-polar, misalnya dietil eter $\left(\mathrm{C}_{2} \mathrm{H}_{5} \mathrm{OC}_{2} \mathrm{H}_{5}\right)$, kloroform $\left(\mathrm{CHCl}_{3}\right)$, benzena, heksana dan hidrokarbon lainnya (Novika, dkk., 2013).

Penentuan kadar lemak dalam penelitian ini menggunakan metode ekstraksi soxhlet. Pada ekstraktor soxhlet, pelarut dipanaskan dalam labu didih sehingga menghasilkan uap. Uap tersebut kemudian masuk ke kondensor melalui pipa kecil dan keluar dalam fase cair, selanjutnya pelarut masuk ke dalam selongsong yang berisi padatan. Pelarut akan membasahi sampel dan tertahan di dalam selongsong sampai tinggi pipa sifon sama dengan tinggi pelarut diselongsong. Pelarut seluruhnya akan mengalir masuk kembali ke dalam labu didih dan begitu seterusnya hingga diperoleh larutan jernih. Setelah itu menguapkan pelarut dengan tekanan dan suhu yang sesuai sampai diperoleh ekstrak kering. Pelarut yang digunakan adalah n-heksana, karena heksana bersifat non polar dan dapat melarutkan lemak yang bersifat non polar (Bintang, 2010).

Ekstrak kemudian dikeringkan dalam oven sampai diperoleh berat konstan pada suhu $100^{\circ} \mathrm{C}$ $105^{\circ} \mathrm{C}$. Tujuan dari pengeringan ini agar lipid bebas air dan sisa pelarut dengan cepat (Bintang, 2010). Penentuan berat lemak dalam sampel digunakan perhitungan selisih berat labu sebelum dan sesudah ekstraksi, sehingga diperoleh kadar lemak yang terlihat pada Gambar 5.

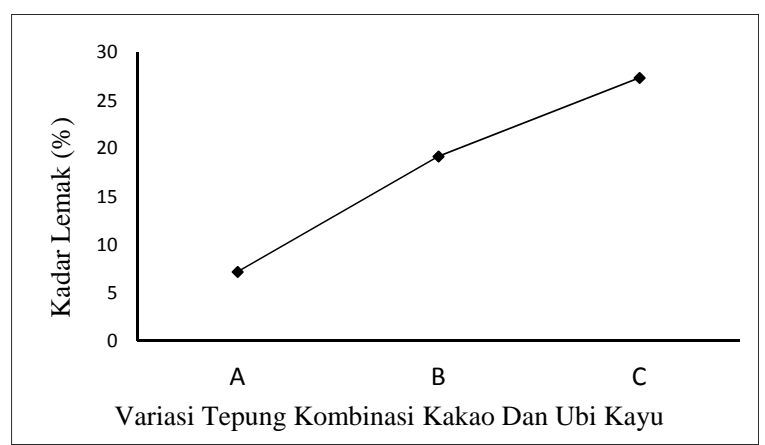

Gambar 5. Hubungan antara kadar lemak dan variasi tepung kombinasi kakao dan ubi kayu.

Berdasarkan Gambar 5 terlihat bahwa kadar lemak pada tepung kombinasi variasi A lebih rendah jika dibandingkan pada variasi $\mathrm{B}$ dan $\mathrm{C}$. Kadar lemak dari masing-masing variasi yaitu berturut-turut $7,2 \%, 19,2 \%, 27,4 \%$. Hal ini sesuai dengan pendapat Mulato, dkk. (2005) yang menyatakan bahwa komponen kimia terbesar di biji kakao adalah lemak, dimana semakin banyak penambahan tepung kakao dalam variasi maka semakin tinggi kadar lemak.

Lemak merupakan komponen penting dalam pembuatan makanan seperti biskuit, karena berfungsi sebagai bahan untuk menimbulkan rasa gurih, menambah aroma dan menghasilkan tekstur produk yang renyah. Akan tetapi kadar lemak yang tinggi tidak baik untuk kesehatan, berdasarkan Badan Standarisasi Nasional(2009) kadar lemak dari tepung yaitu sebanyak 1,5\% - 5\%.

\section{Uji kesukaan}

Uji kesukaan merupakan faktor terpenting untuk mengetahui penerimaan panelis terhadap suatu produk baik makanan maupun minuman. Uji kesukaan yang dilakukan yaitu terhadap tingkat kesukaan biskuit yang dibuat dari tepung kombinasi kakao dan ubi kayu. Hal ini dilakukan untuk menentukan tingkat penerimaan konsumen terhadap produk yang dihasilkan. Menurut Setyaningsih, dkk.(2010) bahwa tujuan analisa sensori adalah sebagai pengujian terhadap bahan makanan berdasarkan kesukaan dan kemauan untuk mempergunakan suatu produk. Suatu penilaian bahan pangan sifat yang menetukan diterima atau tidak suatu produk adalah sifat indrawi.

Tingkat kesukaan merupakan hal yang terpenting dalam menentukan penerimaan atau penolakan suatu bahan pangan oleh panelis. Tingkat kesukaan juga merupakan salah satu uji untuk mendapatkan hasil yang diinginkan karena inti dari penelitian ini adalah untuk mendapatkan hasil yang terbaik yang telah di uji oleh beberapa 
panelis.Hasil uji kesukaanbertujuan untuk mengetahui tingkat respon dari panelis mengenai kesukaannya terhadap biskuit yang dihasilkan pada masing-masing perlakuan.Cita rasa makanan merupakan salah satu faktor penentu bahan makanan. Makanan yang memiliki rasa yang enak dan menarik akan disukai oleh konsumen.Hasil Uji kesukaan dapat dilihat pada Gambar 6 .

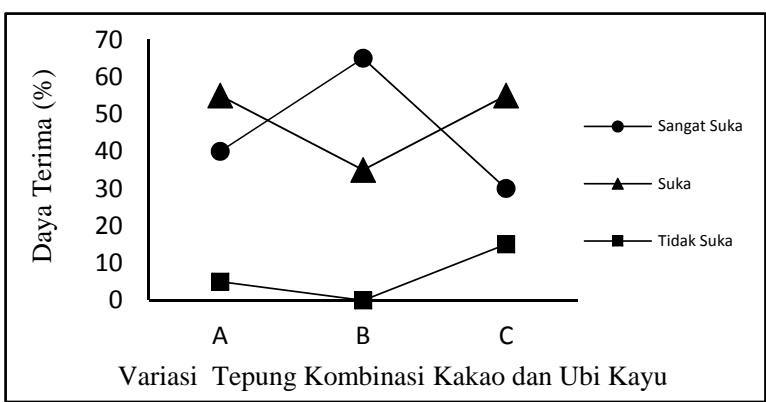

Gambar 6. Hubungan antara daya terima dengan variasi tepung kombinasi kakao dan ubi kayu.

Berdasarkan Gambar 6, menunjukkan bahwa dari segi tingkat kesukaan biskuit, variasi B lebih disukai oleh panelis yaitu untuk opsi sangat suka sebesar 65\% yang terdiri dari 45\% konsumen dan $20 \%$ pedagang kue. Variasi B merupakan perbandingan 50: 50 antara tepung kombinasi kakao dan ubi kayu. Hal ini diduga karena selera dari masing-masing panelis yang lebih menyukai biskuit dengan variasi 50:50 tepung kombinasi kakao dan ubi kayu serta penambahan tepung kakao dan ubi kayu sudah tidak bisa menutupi bahan yang mempengaruhi rasa biskuit yang dihasilkan. Hal ini sesuai dengan pernyataan dari Omobuwoajo (2003) bahwa konsistensi bahanbahan yang digunakan akan mempengaruhi citarasa yang ditimbulkan oleh bahan tersebut. Perubahan tekstur atau viskositas bahan dapat ditimbulkan oleh bahan tersebut untuk merubah bau dan rasa karena dapat mempengaruhi kecepatan timbulnya rangsangan terhadap sel reseptor oleh faktor dari kelenjar air liur.

\section{Kesimpulan}

Hasil penelitian menunjukkan bahwa tepung kombinasi kakao dan ubi kayu dengan beberapa perbandingan variasi yaitu variasi A (25\%:75\%) memiliki kadar air 18,0\%, abu 2,2\%, karbohidrat $2,7 \mathrm{mg} / 100 \mathrm{~g}$, protein $1,7 \%$, lemak $7,2 \%$. Variasi B (50\%:50\%) memiliki kadar air 4,0\%, abu 3,4\%, karbohidrat $63,9 \mathrm{mg} / 100 \mathrm{~g}$, protein 4,8\%, lemak 19,2\%, dan variasi C (75\%:25\%) memiliki kadar air 2,0\%, abu 9,4\%, karbohidrat $127,9 \mathrm{mg} / 100 \mathrm{~g}$, protein $6,7 \%$, lemak $27,4 \%$. Kandungan nutrisi tepung kombinasi kakao dan ubi kayu dengan beberapa variasi terjadi peningkatan, khususnya kadar abu, karbohidrat, protein, dan lemak dengan penambahan tepung kakao sebanyak $75 \%$ tetapi kadar air turun, dan untuk uji kesukaan yaitu perlakuan yang terbaik pada variasi B (50:50).

\section{Ucapan Terima kasih}

Penulis mengucapkan terima kasih kepada seluruh pihak yang telah membantu penelitian ini, khususnya kepada laboran Laboratorium Kimia Fakultas Keguruan dan Ilmu Pendidikan dan laboran Laboratorium Agroteknologi Pertanian Universitas Tadulako Palu, Sulawesi Tengah atas semua bantuannya selama penulis melaksanakan penelitian.

\section{Referensi}

Anonim. (2010). Pengolahan roti. Palembang: Bogasari, BBC.

Apriantono, A., Dedi, F., Puspitasari, N., Sedarmawati \& Slamet, B. (1989). Analisa pangan. Bogor: IPB Press.

APTINDO. (2014). Industri tepung terigu nasional Indonesia. Retrieved 28 November, 2015,fromhttp://www.aptindo.or.id/pdfs/Upd ateoverview11juli2014.pdf

Badan Standarisasi Nasional. (1992). SNI mutu dan cara uji biskuit (SNI 01-2973-1992). Jakarta: Badan Standarisasi Nasional.

Badan Standarisasi Nasional. (2009). SNI tepung terigu sebagai bahan makanan (SNI 3751:2009). Jakarta: Badan Standarisasi Nasional.

Bintang, M. (2010). Biokimia teknik penelitian. Jakarta: Erlangga.

Daud, M., Safii, W. \& Syamsu, K. (2012). Biokonversi bahan berlignoselulosa menjadi bioetanol menggunakan aspergillus niger dan saccharomyces cereviciae. Jurnal Perennial, 8(2), 43-51.

Herlina, E. \& Nuraeni, F. (2014). Pengembangan produk pangan fungsional berbasis ubi kayu (manihot esculenta) dalam menunjang ketahanan pangan. Sains Dasar, 3(2), 142-148.

Hutepea, P. (2010). Pembuatan tepung biji durian (durio zibethinus murr) dengan variasi perendaman dalam air kapur dan uji mutunya. Skripsi. Medan: Universitas Sumatera Utara.

Igfhar, A. (2012). Pengaruh penambahan tepung labu kuning (cucurbita moschata) dan tepung terigu terhadap pembuatan biskuit. Skripsi. Makassar: Universitas Hasanuddin.

Kurniawan, S. (2010). Pengaruh lama fermentasi dan konsentrasi $\mathrm{Ca}(\mathrm{OH})_{2}$ untuk perendaman terhadap karakteristik tepung mocaf (modified cassava flour) varietas singkong pahit (pandemir l-2). Skripsi. Surakarta: Universitas Sebelas Maret.

Mulato, S., Widyotomo, S., Misnawi \& Suharyanto, E. (2005). Petunjuk teknis pengolahan produk primer dan sekunder kakao. Jember: Pusat Penelitian Kopi dan Kakao Indonesia. 
Novika, C., Rachmawanti, D., Kawiji \& Anandito, B. K. (2013). Kajian penggunaan tepung millet kuning sebagai substitusi tepung terigu pada karakteristik sensoris, fisikokimia, dan aktivitas antioksidan mi instan ubi jalar ungu. Jurnal Teknosains, 2(1), 1-8.

Omobuwoajo, T. O. (2003). Compositional characteristics and sensory quality of biscuit, prawn cracer and fried chips produced from breedfruit. Food Science \& Emerging Technology, 4, 219-225.

Pongsawatmanit, R., P, Thanasukarn \& Ikeda, S. (2002). Effect of sucrose on RVA viscosity parameters, water activity and freezable water fraction of cassave starch suspensions. Science Asia, 28, 129-134.

Qalsum, U. (2015). Analisis kadar karbohidrat, lemak dan protein dari tepung biji mangga (mangifera indeca l) jenis gadung. Skripsi. Palu: Universitas Tadulako.

Reski, A. M. (2012). Pemanfaatan ekstraksi kulit ari biji kakao (theobroma cacao l) pada produk cookies cokelat. Skripsi. Makassar: Universitas Hasanuddin.

Sadli. (2014). Analisis kandungan karbohidrat, lemak dan protein dari biji durian (durio zibethinus murr) dengan variasi waktu pengukusan. Skripsi. Palu: Universitas Tadulako.

Sediaoetama, A. (2008). Ilmu gizi. Jakarta: Dian Rakyat.
Setiyono, L. (2011). Pemanfaataan biji kurma (phoenix dactylifera l.) sebagai tepung dan analisis perubahan mutunya selama penyimpanan. Skripsi. Bogor: Institut Teknologi Bogor.

Setyaningsih, D., Apriyantono, A. \& Sari, M. P. (2010). Analisis sensori untuk industri pangan dan agro. Bogor: IPB Press.

Sovia, V. J. (1978). The breeding of cocoa (theobroma cacao l). Tropical Agricultural Research, 11, 161-168.

Sudarmadji, S. (1989). Analisa bahan makanan dan pertanian. Yogyakarta: Liberty.

Suherman, Solfarnina \& Rahmawati, S. (2014). Pemulihan dan peningkatan buah kakao dengan cara pemberian suplemen unsur hara dari tonasinya yang diblending dengan kitosan serta pemanfaatannya untuk biskuit-kripik (bispik). Palu: Lembaga Penelitian Universitas Tadulako.

Tejasari. (2005). Nilai gizi pangan. Yogyakarta: Graha Ilmu.

Tjitrosoepomo, H. S. (1998). Botani umum. Yogyakarta: Universitas Gadjah Mada Press.

Winarno, F. G. (2004). Kimia pangan dan gizi. Jakarta: Gramedia Pustaka Utama. 